\title{
HISTORY EDUCATION IN CURRICULUM 2013: A NEW APPROACH TO TEACHING HISTORY
}

\author{
Said Hamid Hasan ${ }^{1}$
}

\begin{abstract}
There has been so many findings and thoughts indicating that teaching history is dominated by what teachers tell of what happened in the past as it is written in the textbooks or reference books. Students listen, read, and memorize the narration and the more details the student could memorize the higher mark she/he will get. The plan for teaching history, syllabus or lesson plan, shows a high level of consistency amongst the learning objectives, teaching processes, and assessment of student learning outcomes. Memorize of historical facts and the reproduction of historical narratives as indication of student's understanding of historical events, the transmission of information from teacher to student to realize the objectives, and the use of pencil and paper test to assess student level of achievement are the common practices in school from primary to secondary education. It would be no surprise if teaching history at the higher level of education would follow the same path. Public still consider a good scholar or historian in this case, is measured by the amount of knowledge she/he can memorize and she/he should be able to answer some many questions of the facts of historical events. In fact, there is no question of how many a student has in her/his memory apart from what is questioned.
\end{abstract}

Key words: curriculum 2013, history education

\section{Introduction}

Starting the academic year of 2013, the Government of Indonesia introduced a new curriculum called the 2013 Curriculum following Indonesia education tradition in naming a curriculum. In year 2013, the curriculum was implemented in Year 1, 4, 7, and 10 of some selected schools and classes which were mandated. In nature, every new curriculum brings innovations and it is also the reasons for the development of the 2013 Curriculum. In fact, since the 1975 Curriculum, the 2013 Curriculum brings innovations for nearly all dimensions of a curriculum from the development of curriculum ideas, designs, process, and implementation. As the content of 2013 Curriculum those innovations also apply to history education and these make the shift of history education in objectives, content, process, and assessment. These changes are the efforts to meet all thought of a new history teaching as put forwards by many experts in the field.

To put the discussion of history education in the 2013 Curriculum, this writing will start with the discussion on 2013. This approach is important as it will provide a

\footnotetext{
${ }^{1}$ Said Hamid Hasan, Professor Emeritus History Education (UPI) and the Operational Chairman of 2013 Curriculum Development Team. For academic interest, the author can be contacted through the office address: Setiabudhi Street, No. 229, Bandung, and email address: eshamidhasan@gmail.com.
} 
solid background information to understand the shift in the teaching of history. A similar thought is also in mind to have a discussion on history teaching as put forward by the 2006 Curriculum so it will provide an adequate basis for recognizing differences with history teaching put forward by the 2013 Curriculum.

\section{The 2013 Curriculum}

The 2013 Curriculum are curricula for primary and secondary education. In the Indonesian context of education, the primary education consists of primary or elementary school called Sekolah Dasar (SD) and junior secondary school called Sekolah Menengah Pertama (SMP). Secondary Education consists of General Secondary School called Sekolah Menengah Atas (SMA) and Vocational Secondary School called Sekolah Menengah Kejuruan (SMK). At present, the idea of the 2013 Curriculum is also being used for the development of Childhood Education (PAUD) and Higher Education (university, D3 and D4) curricula. This policy in itself is a new one in Indonesia education and it might also a new one in education in many countries as well.

Since 2003, Indonesia has applied standard-based education which was preceded by the change of government system from centralized to district autonomy. Entering a new period called Reformation, there were some fundamental changes or amendment on some articles of the 1945 Constitution, and amongst others it concerns with the authority of the provincial and district authority, apart from the change in the power of the Majelis Permusyawaratan Rakyat (People Assembly) that has no power to elect president. By the issue of the law of Civil Government education has been authorized to local government although the central government has some power for the development of educational system and to set national standards for education.

There are eight standards which are outcomes competency standard, content standard, process standard, and assessment standards which are closely related with the development of curriculum and facilities standard, management standard, library, and teachers which are directly related with the implementation of a curriculum. In the new educational context, curriculum should be developed by the central, provincial, and local government. The central government has the authority to develop curriculum ideas, structure, and content design. In the structure there are some courses which mandatory by the law and some courses are related with the need of the nation.

Innovation in the curriculum ideas of the 2013 Curriculum is related with philosophy of the curriculum, the aims of the curriculum, theoretical model of competency-based curriculum, content design, process, assessment of students outcomes. In addition, it is also concerned with strategy for implementation and curriculum evaluation. However, these two dimensions of curriculum development will not be discussed in the present article as they are not basic to understand the main innovative features of history education as advocated by the 2013 Curriculum.

\section{Philosophy of the 2013 Curriculum}

Philosophy for curriculum development is very important at least for two reasons. One, as put forward by Schubert (1986:112): "philosophy lies at the heart of educational endeavor. This is perhaps more evident in curriculum domain than in any other, for 
curriculum is a response to the question of how to live a good life". Philosophy directs curriculum developers in shaping up the all components of curriculum. Therefore, Oliva (1997:190) insisted that the curriculum committee should be cognizant of the major principles of the leading schools of philosophy, particularly essentialism and progressivism. They should know where they stand as individuals and as a group in the philosophical spectrum. Thus, it could hardly be possible that there is a good and sound curriculum development which is not based on a philosophy. Secondly, as mentioned by Tanner and Tanner (1980:103) that "philosophy serves as both a source and an influence for educational objectives and curriculum development". Consequently, philosophy should be stated explicitly and clearly, shared by a curriculum team and those who will be responsible for implementing the curriculum.

Philosophy of the 2013 Curriculum is stated as follows (Peraturan Menteri Pendidikan dan Kebudayaan Nomor 67, 68, 69, 70 Tahun 2013):

1. Education roots in the culture of the nation and directed for a better development of present and future lives of the nation.

2. Students inherit and play an active role to develop the culture for the betterment of present and future lives. The glorious past should direct the students to learn the present and the bases for them to develop their future lives.

3. Education is aimed at the development of intellectual and academic powers, communication skills, social attitude, care, and participation ability of students
The philosophy of 2013 Curriculum places the role of history in a very pivotal position albeit there is no word of history is mentioned. The glorious past can only be traced through history. Also, the concept of time in history which is past, present and future reflected clearly in the philosophy.

To achieve what the quality of learner the curriculum should develop, therefore, some strands of educational philosophy such as essentialism, perennialism, progressive, humanism, and reconstructionism are eccletically used. Ecclectism is common in the development of curriculum (Oliva, 1997:190) but the use of reconstructionism is never used before. By using this philosophy, school and society is linked and school should be related to the development of the society. School is no longer an educational institution which excludes itself from what happen in society and should be able to contribute to the betterment of society.

\section{The Aims of the 2013 Curriculum}

The aims of the 2013 Curriculum is also new for Indonesia educational context. The aims states:

To prepare Indonesia young generation to have life skills as a personal and citizen who are productive, creative, innovative, affective (religious and social attitudes) and competent to contribute for the betterment of social, national, and political lives, and humanity.

The 2013 Curriculum advocates the learners with the quality of contributing to the advancement of the lives of the society where they live, the live of the nation in political, social, economic, culture, arts, technology 
and others. The curriculum also aims at providing the students with the competency to contribute to the welfare of humanity.

This statement is never explicitly or implicitly stated in previous curricula. This noble statement is actually expressed for the first time by some leaders when they drafted the first Indonesia law of education. To have such a quality, a student should have creativity, innovative, and care for the welfare of the society. By having this quality they will become independent learners and care of what happens, and provide what they have to contribute for a better development of the society.

\section{Theoretical Model of the 2013 Curriculum}

As mandated by the 2003 Education Law, the 2013 Curriculum was developed using competency-based curriculum. Competency-based curriculum was also the model for the previous 2006 Curriculum, however, there are some fundamental differences in applying the model for each curriculum. The 2013 Curriculum interprets competency-based curriculum as curriculum that sees all the courses in the interactive processes in providing learning experiences for students to develop their potentials up to the accepted competency level or higher. Thus, each competency is the responsible of every courses (Quillen, 2001). Robust to the principle is specific facts, concepts and procedures exclusive to a particular course. Attitudes, thinking skills, the way to apply general knowledge, and learning abilities are curriculum content which should be developed together by every course and every learning activities.

Furthermore, the 2013 Curriculum recognizes that competencies are indicated by the ability of students to create right answers more than one to a question. The students are encouraged to think that so many correct answer they could think and apply to solve the real life problems. Competency is not defined as a standard answer or procedure that apply for a problem or a question except when it deals with a very specific fact likelaws, rules, historical facts, geographical facts, and ceremonial procedures such as there is only one answer for the declaration of Indonesia Independence or the name of capital city of each nation.

\section{Content Design of the 2013 Curriculum}

There is a new definition of curriculum content applied for the 2013 Curriculum. Alongside with the use of competency-based curriculum model, curriculum content is not limitedtofacts, concepts, theories, procedures as adopted by previous curriculum but it also covers attitudes, thinking skills, social skills, and cultural skills. The source of the curriculum content is not limited to academic disciplines but also society, culture, and the students.

As previous 2006 Curriculum, the content is called Kompetensi Dasar (basic competencies). However, thewaytodevelop and organize the Kompetensi Dasar is different from the previous curriculum. As curriculum is defined as an educational program for a particular level of education or a school, and not as a list of courses. The Kompetensi Dasar of the 2013 Curriculum is derived from Kompetensi Inti (core competencies) and specific content from each courses. The Kompetensi Inti is the organizing element of Kompetensi Dasar and therefore all courses have the same Kompetensi Inti. Derived from Standar 
Table 2.1: Relationship between Kompetensi Inti (Core Comptency) and Kompetensi Dasar (Basic Competency)

\begin{tabular}{|c|c|c|c|}
\hline $\begin{array}{c}\text { Core } \\
\text { Compt- } \\
\text { ency }\end{array}$ & \multicolumn{3}{|c|}{ Course and Basic Compt- } \\
\cline { 2 - 4 } & History & English & $\begin{array}{c}\text { Math- } \\
\text { emat- } \\
\text { ics }\end{array}$ \\
\hline $\begin{array}{c}\text { KI-1: } \\
\text { Religious } \\
\text { Attitudes }\end{array}$ & KD-1 & KD-1 & KD -1 \\
\hline $\begin{array}{c}\text { KI-2: } \\
\text { Social At- } \\
\text { titudes }\end{array}$ & KD-2 & KD-2 & KD -2 \\
\hline $\begin{array}{c}\text { KI-3: } \\
\text { Knowledge }\end{array}$ & KD-3 & KD-3 & KD-3 \\
\hline $\begin{array}{c}\text { KI-4: } \\
\text { Knowledge } \\
\text { Utilization }\end{array}$ & KD-4 & KD-4 & KD-4 \\
\hline
\end{tabular}

Kompetensi Lulusan (competency outcome standard). The Kompetensi Inti has four components which are religious attitudes, social attitudes, knowledge, and knowledge utilization. The knowledge utilization is from the new taxonomy of educational objective developed by Marzano and Kendall (2007). Thus, all courses must have Kompetensi Dasar for each of the component.

KD-1 and KD-2 for each course are not necessarily derived from the knowledge or skills from each course, it can be developed free from such content. Therefore, the KD-1 and KD-2 for every course can have similar or even the same sentences. $\mathrm{KD}-3$ is the knowledge of the course and $\mathrm{KD}-4$ is the way to use the knowledge for different context inside or outside a school.

Furthermore, the content or $\mathrm{KD}$ is treated in different ways amongst those for elementary school, junior secondary school, and senior secondary school. Thematic integrative approach is used for elementary school KDs as such KDs from each course are linked in a sub-theme and those sub-theme form a theme. For junior secondary school, there are two approaches used a monodisciplinary approach for all courses except for social studies and science. Integrated social studies and science are for these two courses. For general senior secondary school mono disciplinary approach is used while for vocational senior secondary school KDs are categorized under the job orientation.

\section{Process Dimension of the 2013 Curriculum}

The process dimension refers to the design of learning process in a curriculum. The 2013 Curriculum advocates student active learning. It is written in the curriculum document that student should be active to explore knowledge, skills, and develop the attitudes. To provide experiences for the students to have ample opportunities to be active, the 2013 Curriculum advocates what is called "scientific approach" and allocates more time for student to learn. The scientific approach model has been modified for the 2013 Curriculum so that it can be applied to each course and not necessarily limited to natural science courses such biology, physics, or chemistry.

The model has five activities which should be developed in the learning-teaching process and they are not a syntax of a teaching or learning model. They are observing, questioning, exploring/experimenting, analyzing, and communicating. Each of these activities is considered as a competency and, therefore, it should be planned and assessed. Each of these activities is potentially develop competencies which are pertinent to the 2013 Curriculum. The following table shows the relationship between those five activities with the competencies. 
SAID HAMID HASAN,

History Education in Curriculum 2013: A New Approach to Teaching History.

Tabel 2.2: Scientific Approach for Learning Activities

\begin{tabular}{|l|l|}
\hline Activities of Scientific Approach & \multicolumn{1}{|c|}{$\begin{array}{c}\text { Competencies developed by the } \\
\text { activities }\end{array}$} \\
\hline Observing & $\begin{array}{l}\text { Students read/observe/listen to develop pa- } \\
\text { tience, sincerity, to differentiate general and } \\
\text { specific information/feature/character, think } \\
\text { analytically, critically, deductive, and com- } \\
\text { prehensive. In history, they observe historical } \\
\text { account(s) or text, document, artifacts (physi- } \\
\text { cal, cultural, social). }\end{array}$ \\
\hline Questioning & $\begin{array}{l}\text { Students ask questions from what is observed, } \\
\text { to develop ability to formulate questions, cre- } \\
\text { ativity, curiosity, and critical minds. They for- } \\
\text { mulate questions concerning an historical ac- } \\
\text { count. }\end{array}$ \\
\hline Exploring & $\begin{array}{l}\text { Students explore or collect information } \\
\text { through experiment, read from other sources } \\
\text { of information, observe from environment, in- } \\
\text { terview human resources to develop sincerity, } \\
\text { honesty, respect other opinions, communica- } \\
\text { tion skills, ways to determine valid resources, } \\
\text { work cooperatively and collaboratively. In } \\
\text { history, students collect more resources (docu- } \\
\text { ments or text), artifacts, or interview resources } \\
\text { persons especially the ones who took parts in } \\
\text { an historical event the students learn. }\end{array}$ \\
\hline Communicating & $\begin{array}{l}\text { Students analyze information available from } \\
\text { exploring activities to develop honesty, disci- } \\
\text { pline, rule obedient attitudes, hardworking, } \\
\text { skills in applying scientific procedures, analyt- } \\
\text { ical thinking, In history, students reconstruct } \\
\text { information collected from data collection ac- } \\
\text { tivity and make their own history account. }\end{array}$ \\
\hline Analyzing & $\begin{array}{l}\text { Students communicate the result of analysis } \\
\text { they made, to develop honesty, sincerity, sys- } \\
\text { tematic thinking, the use of proper terms and } \\
\text { language. In history, they communicate what } \\
\text { they have constructed as their own history in } \\
\text { analyzing activity that may take the format of } \\
\text { writing historical account, video, photos, or } \\
\text { other communication formats. }\end{array}$ \\
\hline
\end{tabular}

The Assessment of Student Learning Outcomes

To serve the aims of the curriculum and the principle that the students should develop more alternative answers to a question, the 2013 Curriculum advocates classroom assessment approach and authentic assessment. In the classroom assessment approach the students are assessed formatively and when the result is not satisfactory then the student(s) is provided with remedial treatment. By this 
approach there should not be one single student is left behind for her/his poor achievement in an assessment event. It is believed that every student can reach the mastery level of a competency once she/he is provided with proper and suitable treatment. Poor achievement is due to some learning factors which can be improved by correcting the learning factors.

Authentic assessment is encouraged as it gives the students opportunity to demonstrate their knowledge and abilities to use their knowledge, abilities and ways of thinking, attitudes, capabilities to produce products, and so on through their own styles not teacher's style which might inhibit the students ability. Moreover the objectivetype of questions prevent the students to demonstrate their real competencies because they only react to one single correct answer. In real life, the students and members of society should deal with problems which the answer is already prepared and they can only need to choose. Authentic assessment is isomorphic to real life situation the student should face.

In terms of assessment, the 2013 Curriculum also advocates the use of $1-4$ to score the students works and transform these scores to A, B, C, and D replacing the very long tradition 1-10 scale. Shortly, there are fundamental innovation put forward by the 2013 Curriculum in terms of assessment of students learning outcomes. What is the most important the 2013 Curriculum brings about the curriculum close to the real life situation.

\section{The Position of History Education in 2013 Curriculum}

In the structure of the 2013 Curriculum history education takes four forms, namely, integrated thematic, integrated social studies, history of Indonesia, and history. Integrated thematic is for elementary school, integrated social studies is for junior secondary school, history of Indonesia is for general and vocational senior secondary school, and history for general senior secondary school.

The following figure depicts the status of history education in the curriculum.

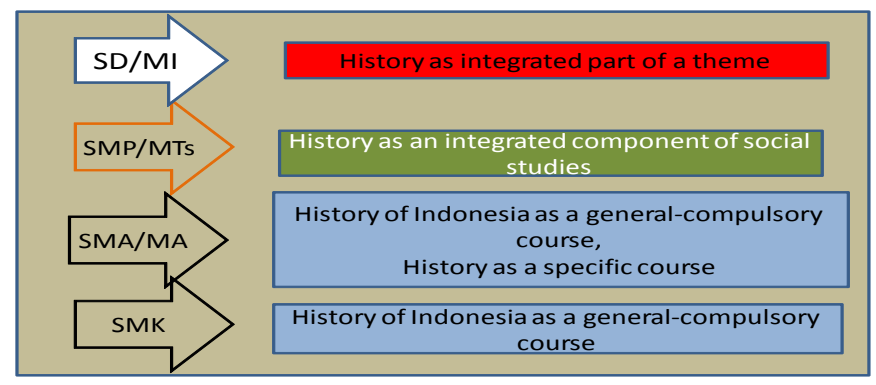

SD/MI (Sekolah Dasar/Madrasah Ibtidaiyah) is primary school. SD is managed under the Ministry of Education and Culture (MOEC) while MI is under the management of the Ministry of Religious Affairs (MORA). SMP/MTs (Sekolah Menengah Pertama/ Madrasah Tsanawiyah) is junior secondary school. SMP is under the management of MOEC while MTs is under the management of MORA

SMA/MA (Sekolah Menengah Atas/ Madrasah Aliyah) is senior general secondary school. SMA is under the management of MOEC while MA is under the management of MORA. SMK (Sekolah Menengah Kejuruan) is senior vocational school which is under the management of MOEC and there is none senior vocational school under the manaagement of MORA albeit it is mentioned in the 2003 Law of National Education

For primary school, the 2013 Curriculum uses transdisciplinarity and reconstructionism philosophies. 
Transdisciplinarity allows the content of the curriculum is not limited and confined to a single discipline. In fact, this philosophy places curriculum developers of 2013 Curriculum a liberty to develop content, in this case competencies, from any sources other than disciplines. society is a very rich and realistic sources for the primary school of education. The reconstructionism advocates the abolishment of wall separated school from the real every life of the society. Curriculum content developed by these philosophies is very suitable for students of primary school as they should not introduce with each discipline such as biology, physics, sociology, history, economy and so on as something separated. At the age of primary school, they are not educated to be a scientist or the like but to be a person with holistically developed personality. Gestalt psychology is very much in support of this position as it is said that people learn from totality to pieces. Primary school, especially the first three earlier classes, are basically should develop personality of the students in total not divided by the interest of the disciplines.

In this context, history content in Year 1-3 is integrated with content of others. Topics such as to memahami Nilai-nilai Persatuan pada masa Islam (to understand the values of unity in the period of Islam), memahami Nilai-nilaiPersatuanpadamasapenjajahan, pergerakan nasional dan kemerdekaan (to understand the values of unity in the periods of colonial, national awakeness, and independence) are taught within the course of Pancasila and Kewarganegaraan (Pancasila and Citizenship Education).

In Year $4-6$, the content of history is organized within the social studies. Together with economy, sociology, and geography history is an integrated parts of social studies. Topics such as "memahami manusia, perubahan dan keberlanjutan dalam waktu pada masa praaksara, Hindu Budha, Islam dalam aspek pemerintah, sosial, ekonomi, dan pendidikan (to understand man, change and continuity in the period of pre-history, Hindu, Budha, Islam in aspects government, social, economy, and education); mengenal perubahan dan keberlanjutan yang terjadi dalam kehidupan manusia dan masyarakat Indonesia pada masa penjajahan, masa tumbuhnya rasa kebangsaan serta perubahan dalam aspek sosial, ekonomi, pendidikan dan budaya (to recognize the change and continuity in the Indonesian society and man in the period of colonial, the earlier time of nationalism, and in the aspects of social, economy, education, and culture); menunjukkan pemahaman sebab dan akibat terjadinya perubahan masyarakat Indonesia dari masa pergerakan kemerdekaan sampai dengan awal Reformasi (to show understandings of the changing in Indonesian society since independence movement to the beginning of reformation)".

Students of Year 4-6 are cognitively at the beginning of the period of formal operational thinking. This means that they can already be able to develop abstract thinking. Abstract thinking is important for academic thinking as all the facts, concepts, theory, historical events, and historical time are all abstract. All historical concepts such as change, continuity, events, power, nation, challenge, period, past, pre-history, kingdom, and so on are all abstract. The distance in time between the students and an historical events contributes to the abstract nature of the historical concepts. These abstract nature of historical concepts and events makes history education is something hardly be fully understood and it requires the ability of abstract thinking of students to comprehend. 
Students of Year 4 up are in the position to have the ability to think in abstract and thus be in a very adequate position to comprehend historical events although they are still at the earlier stage. The 2013 Curriculum provides the opportunity for students to begin with learning of history.

For junior secondary education, history education is also a part of social studies. The KDs of social studies are structured by geography. Geography concept of space is conceived as the the most accomodating concepts just like the concept of time in history. However, different from time which is very strict in application, the concept of space is open in application and manipulatable. As with time, no human activities can be separated from a space, a place where they do their daily activities. It is also true that no human activity can be done without the aspect of time but time has limitation where no past activities can be replicated while space or place has no such rigidity.

The way to organize the content of history in junior secondary social studies follows the principle suggested by Scriven(1974) and by Hanna (1960). Scriven suggested the use of geography or history concept as the integration element for social studies. But, as it is discussed, 2013 Curriculum uses geography instead of history. Hanna suggested the use of Expanded Community Approach to develop content. The 2013 Curriculum uses this approach by placing the contentwhichis themostclosetothestudents, themselves and the family, their immediate physical, cultural and social environment, important document for a family extended to the farthest environment. History content is designed as such, beginning with history of a family of the students, official and private important document a family has, kecamatan and go on to the history of the nation and Asian countries.

By consideration of their thinking and affective abilities, the scope of history for junior secondary school starts from prehistoryperioduptotheperiod of Reformation. As in the Year 4-6 where the students learn about some historical figures or leaders. The learning about these historical actors is important to learn about values of those which can be applicable at the present time or adjusted as needed by the spirit of present time. Soekarno and Hatta and other leaders of the nation are learned in their role in historical perspectives, the values they hold for their lives, they views about the nation, and the way they contribute to the existent, development, and the glory of the nation.

The content of junior secondary history content cover many aspects of human lives such as economy, social, cultural, government. thus, in addition to learn about the formal history content, students of junior secondary school also learn history in their immediate environment. In most cases they should learn them from what is told and handed orally from generation to generation. They study them following the time frame of history of Indonesia. In that way, students what happened in their immediate space in the period of pre-history, Hindu-Buddha, Islam, colonial, awakening of Indonesia nationalism, independence movement, the declaration of independence, up to present time. By this approach, the 2013 Curriculum encourages students to know and understand the history of their own region and appreciate the contribution of the local historical events and the contribution of local people and leaders to the nation. 
This kind of approach in history education, to study the history of the nation at the same time with the local historical events will give the students a fully aware of what happened. They will know about their cultural, social, economy, geographical space the society where they live and at the same time they also know and understand of the development of their nation historically (Hasan, 2005). They will also be in position to appreciate the society to the history of the nation through their analysis about the contribution of their local historical events to the history of the nation (Hasan, 2001). In that way, the students also understand that it is what happened in their locals make the nation as what it is now.

The position of history education in secondary education level promotes a new approach. There are two courses concerning history, namely, Sejarah Indonesia (History of Indonesia) which is compulsory for every students of general senior secondary school (SMA/MA), and of vocational senior secondary school (SMK). The second one is labeled Sejarah (History) for those students who are interested in history. The History is selected by students of SMA in two ways, it is compulsory for those select Social Sciences stream and optional for those students of other academic stream

in the structure of SMA Curriculum there are three academic streams students could choose, mathematics and natural science, social sciences, culture and languages. Students who choose social sciences stream should study history, geography, economy, and sociology as academic studies and compulsory. In addition, they should select two courses in Year $\mathrm{X}$ and one course in Year XI and Year XII from other academic streams. Students of mathematics and natural science study mathematics, biology, physics and chemistry as compulsory courses and select two courses in Year X and one course in Year XI and Year XII which might be history together with students from social sciences stream. The same pattern also applies for students who choose Culture and Language stream where they should study anthropology, Indonesia, English and one foreign language from Language Other Than English.

These two courses, Sejarah Indonesia and Sejarah, are different in objective and nature. The objectives of Sejarah Indonesia is for the development the students personality as a citizen, of historical awareness, memory collective as a citizen of a nation, nationalism, unity in diversity, a strong sense as a nation, and historical thinking. The objectives of Sejarah is more towards the development of historical awareness, historical thinking, and historical skills. However, they have similarity in developing critical and analytical thinking.

By these objectives history education shift from the concerns of having knowledge and understanding to develop thinking as put forward by many scholars in the field (Cooper, 1992; Hasan, 2001, 2010b; Husband, Kitson, Pendry, 2003; Wineburg, 2001)). By this approach it is expected that history will put students in a very challenging in doing things as they will create their own history (Boris, 2005). It is also designed that this approach will put the image that history is a matter of memory historical facts (Hasan, 2010a) to a position that history is related with the present live and the future (Hasan, 1999; Hasan, 2010b; Oliva, 1997; Wineburg, 2001).The development of historical thinking will give the students a complete different but better learning experiences in learning history. 
The nature of the content of these two courses is also different. Sejarah Indonesia covers the history of Indonesia including local histories while Sejarah covers history of Indonesia and the world. The content of Sejarah Indonesia is also related with the success of Indonesian people in their contribution to the world present lives such as non-block movement, ASEAN, peace movement where Indonesian army is also used by United Nations for keeping peace in many parts of the world. In terms of time, both covers historical events from the earliest time of human presence to the recent period. However, the development of world history content is based upon the impact of an world historical event to history or society of Indonesia. The selection is done as such that the history of Indonesia is the centre of the interest and also the impact of such an event to the lives of the people today.

The difference in historical thinking between Sejarah Indonesia and Sejarah is also characterized by level 6. For Sejarah analyzing skills and constructing skills are more difficult than in Sejarah Indonesia. Here, at the level 6 (Peraturan Menteri Pendidikan dan Kebudayaan nomor 64 tentang Standar Isi), the students are asked to develop critical ability in identifying different points of interpretation between the government official point of view and one of independent historian point of view in interpreting an historical event. The student is also asked to have their own interpretation so that they can have their own history. For students of Sejarah Indonesia are asked only be able to identify the differences and understand the reason of the differences.

\section{The Process of Teaching in History Education}

The 2013 Curriculum emphasizes very much on the value, skills, and knowledge development in proper balance. For teaching the 2013 Curriculum implements scientific approach in teaching which strongly provides students with activities. This approach correlates nicely with the character of KDs in a sense that the development all KDs can be facilitated by this approach.

The scientific approach used by the 2013 Curriculum has been modified from its original features so that all content from all courses can use this approach. As mentioned in curriculum document (Peraturan Menteri Pendidikan dan Kebudayaan, Nomor 81A Tahun 2013) the scientific approach has the following steps: observing, questioning, exploring, analyzing, communicating as already elaborated in the previous section on the 2013 Curriculum in this article.

Theimplementationofscientificapproach in teaching of history can take many forms. However, one thing is obvious that those five steps are competencies or skills and as skills the students should master those skills depending on the level of difficulties as set in the Standard of Content (Peraturan Menteri Pendidikan dan Kebudayaan). This means that students should do a lot of exercises. In terms of curriculum implementation, the mastery of those competencies should start from Year 1. Consequently, when they are in Year 4 they already have the basic skills to observe, question, explore or experiment, analyze, and communicate. In Year 6 should be able to develop those skills more rigorous and skillful. However, the use of those skills is in general context not related to a specific 
nature of content of a course. In Year 7-10 the student should reach the level of adequate mastery where they can use the skills in observing things outside classrooms and school context, and it should be connected with the nature of content of each courses of junior secondary school.

In Year 10 the students should be able to apply those skills in general and in specific content of each course they take. For Sejarah Indonesia and Sejarah courses, naturally there are differences and similarities in the way to apply the approach. In general, both courses develop historical thinking which can be the same activities when applying scientific approach but the difference is in the depth of the thinking.

In general, the application of those five skills of the scientific approach for Sejarah Indonesia and Sejarah is as follows.

For Sejarah Indonesia, the use of local resources is pivotal. Students should be encouraged to explore historical events in their local. In that students should also be taught to analyze the relationship between historical events at national level

\begin{tabular}{|c|c|c|}
\hline $\begin{array}{l}\text { Scientific } \\
\text { Approach }\end{array}$ & Application in Teaching of History & What teachers do \\
\hline Observing & $\begin{array}{l}\text { Student listen to explanation from teacher/ } \\
\text { video/human resources/ reading an histori- } \\
\text { cal account, watching a film, video, an artifact, } \\
\text { observe human activities }\end{array}$ & $\begin{array}{l}\text { Teacher provides the resourc- } \\
\text { es then asks students to ob- } \\
\text { serve }\end{array}$ \\
\hline Questioning & $\begin{array}{l}\text { Students pose a question(s) about what has } \\
\text { been observed in the observing activities. At } \\
\text { Year } 10 \text { up the questions should not be con- } \\
\text { cerned with facts but concepts or hypotheti- } \\
\text { cal. } \\
\text { Procedure to collect information can be dis- } \\
\text { cussed or can be done at the beginning of ex- } \\
\text { ploring activities. }\end{array}$ & $\begin{array}{l}\text { Teacher encourages students } \\
\text { to ask question(s). If students } \\
\text { do not pose any question or } \\
\text { there are other aspects stu- } \\
\text { dents do not notice and pose } \\
\text { question, teacher probe to } \\
\text { stimulate students asking } \\
\text { question }\end{array}$ \\
\hline Exploring & $\begin{array}{l}\text { Students read, interviews, observes other re- } \\
\text { sources than what has been observes when the } \\
\text { lesson starts. Documents, newspapers, books, } \\
\text { a legend, person/ people, films, internet, oth- } \\
\text { ers can be explored to collect information } \\
\text { needed for answering the question. }\end{array}$ & $\begin{array}{l}\text { Teacher observes what stu- } \\
\text { dents are doing and provide } \\
\text { assistance and direction for } \\
\text { particular students who have } \\
\text { difficulty (ies). } \\
\text { Teacher teaches students to } \\
\text { master the technicality(ies) } \\
\text { concerning how to find sourc- } \\
\text { es, select them, and collect in- } \\
\text { formation from the sources. }\end{array}$ \\
\hline
\end{tabular}




\begin{tabular}{|l|l|l|}
\hline Analyzing & $\begin{array}{l}\text { Students criticize the validity of the sources } \\
\text { and the information provided by the sources. } \\
\text { Students categorize information they have } \\
\text { collected, give meaning to the category, and } \\
\text { establish connection between or amongst cat- } \\
\text { egories. }\end{array}$ & $\begin{array}{l}\text { Teacher observes what stu- } \\
\text { dents are doing and provide } \\
\text { assistance and direction for } \\
\text { particular students who have } \\
\text { difficulty (ies) }\end{array}$ \\
\hline $\begin{array}{l}\text { Communi- } \\
\text { cating }\end{array}$ & $\begin{array}{l}\text { Students develop skills and use the skills to } \\
\text { write an historical account, to present it in } \\
\text { audio or video forms, or other forms. }\end{array}$ & $\begin{array}{l}\text { Teacher observes what stu- } \\
\text { dents are doing and provide } \\
\text { assistance and direction for } \\
\text { particular students who have } \\
\text { difficulty (ies) }\end{array}$ \\
\hline
\end{tabular}

and contemporary local events. Level of complexity in reconstructing historical event is more simple compared to students of Sejarah. Students of Sejarah should also consider different interpretation available on the same historical event(s).

\section{Students Assessment}

Students assessment is critical as there are so many practices showing that students assessment model and techniques determine significantly the process of teaching. In many cases when the assessment is also concerned with how much knowledge students have then the process of learning turns to be informationprovisionprocesswherelecturing is dominant. In that case, the objectives which formulates values and skills development are then replaced by accident and by assessment be knowledge mastery. Unfortunately, the knowledge mastery is always indicated by how much knowledge possessed by students at the level of very simple. Simple facts, not profound knowledge be important and students should memorize and recall them in a very short time. Education has become an olympiad, the quicker students answer questions correctly and the one who wins are students who can answer most or all questions correctly. No higher thinking process is needed for a such event, students do not need to develop their skills and values in a process-based learning.

Fortunately, it is not the 2013 Curriculum advocates for students assessment. Objective-type of assessment techniques from quantitative measurement alongside with a very rigid indicators are not the 2013 Curriculum suggests. The 2013 Curriculum strongly recommend the use of authentic assessment approach where students can develop their higher order of thinking process and provide more than one correct answer. Various techniques available for authentic assessment such as portfolio, assignment, papers, group discussion, and so on.

By using this authentic approach the teaching of history will stop or at least continuously leaving the multiple choice type of question. By authentic assessment students have ample opportunities to apply what they have learned from history, to relate those with realities in the present lives, to interpret historical facts without any worries that it does not comply with the standard and formal historical accounts done by welltrained historians. Students are free to have their interpretation as long as based upon historical facts. Doing assessment will be very demanding but students can do that without any stress. As what well-trained historians do when they construct a historical story where 
they always be able to read and read again their data, check and recheck their resources and other interpretation, so the students are also in the same situation in doing their assessment.

Of course, some necessary and limited very important historical facts should be memorized by every citizen and that the instrument such as multiple-choice type questions can be used. However, other type of question such as essay type of questions can also be as effective as multiple-choice type questions. historical facts such the day of Indonesia independence proclamation, United States declaration of Independence, other such facts are fixed and cannot be replaced by others for whatever reasons. In this case, it is a compulsory for students to memorize.

\section{Conclusion}

The discussion shows that the 2013 Curriculum will bring a very fundamental change in history education as those curriculum principles shows that there should be a shift from memorizing and factual based education to thinking and value-based education. As a content of the 2013 Curriculum, history education will have fundamental change as well. History as a course to memorize fact will change to history as a course to develop values and critical thinking.

Furthermore, history will also develop national and local awareness of the students and provide them with ways to appreciate the achievement of this nation locally, nationally, and globally. students will appreciate the contribution of this nation to the welfare of human being across the continent in motivating national movement of so many countries, provides good examples in developing the well-being nation. History also uncover some mistakes done in the past and learn from them to make a better lives. History is not taught to blame those mistakes but to make a better efforts a better future lives. History should be learned so the young people, the heritance of the past, will not make the same mistakes twice.

History in 2013 Curriculum is also advocates the use of historical concepts and thinking in learning historical events and connect them with the real live situation. The time frame where all changes and continuity or discontinuity is practiced and be the competencies of students, the present generation or the next generation can make their future better.

\section{REFERENCES}

Borries, B. von (2000). Methods and Aims of Teaching History in Europe: A Report on Youth and History, dalam Knowing Teaching \& Learning History: National and International Perspectives (Eds. Stearns, P.N., Seixas,P., Wineburg,S.). New York: New York University Press.

Burke, J. (Ed.)(1995). Competency Based Education and Training. London: The Falmer Press

Carvalho,S. dan White,H. (2004). TheoryBased Evaluation: The Case of Social Funds. American Journal of Evaluation, 25, 2:141-160.

Cooper, H. (1992). The Teaching of History: Implementing the National Curriculum. London: David Fulton Publishers.

Conley, D. (1999). Statewide Strategies for Implementing Competency-based Admissions Standards. Denver: State Higher Education Executive Officers. 
Cinterfor (2001). Competency-based Curriculum Design. Available at http:// www.ilo.org, tanggal 24 Januari 2014.

Drake, F.D. and Nelson,L.R. (2005) Engagement in Teahing History: Theory and Practices for Middle and Secondary Teachhers. Upper Sadle River, New Jersey: Pearson PrenticeHall

Ferguson,F. (2000). Outcomes-Based Curriculum Development. Available at http://www.c2t2.ca, tanggal 24 Januari 2002.

Hasan, S.H. (1996). Kurikulum dan Buku Teks Sejarah. Keynote paper, presented at National Congress on History. Jakarta, November 13, 1996

Hasan, S.H. (1999). Pendidikan Sejarah Untuk Membangun Manusia Baru Indonesia, Mimbar Pendidikan, XVIII: 2

Hasan, S.H. (2001). Supplemen Kurikulum Sejarah. Jurnal Pendidikan Sejarah, 2001

Hasan, S.H. (2005). Kurikulum Sejarah dan Pendidikan Sejarah Lokal. Seminar Jurusan Pendidikan Sejarah, April 2005

Hasan, S.H. (2010a). Pendidikan Sejarah, Kemana dan Bagaimana? Makalah, di presentasikan di Seminar Asosiasi Guru Sejarah. Jakarta, Maret 2010.

Hasan, S.H. (2010b). The Development of Historical Thinking and Skills in the Teaching of History in the Senior Secondary School Curriculum in Indonesia. Historia: International Journal of History Education, XI: 2, Desember 2010

Husband, C., Kitson, A., Pendry.A. (2003). Understanding History Teaching: Teaching and Learning About the Past in Secondary Schools. Maidenhead, Philadelphia: Open University Press.
Jakubowski,C. (2002). Teaching World History: Problems and Promises Faced by Young Teachers. World History

Levstik,L.S. (2000). Articulating the Silences: Teachers' and Adolescents' Conceptions of Historical Significance, dalamKnowing TeachingandLearning History: National and International Perspectives, Knowing Teaching and Learning History: National and International Perspectives. ed. Stearns,P.N., P. Seixas, dan S. Wineburg.

Marzano, R.J and Kendall, J.S. (2007). The New Taxonomy of Educational Objectives. Thousand Oaks, CA: Corwin Press - A Sage Publication Company.

Percoco, J.A. (1993). A Passion for the Past: Creative Teaching of U.S. History. Portmouth, NH: Heinemann.

Print, M. (1993). Curriculum Development and Design. St. Leonard: Allen \& Unwin Pty, Ltd.

Quillen,D.M. (2001). Challenges and Pitfalls of Developing and Applying a Competency-based Curriculum. Family Medicine, Oktober 2001

Resnick, L. dan K. Nolan (1995). Where in the WorldAre World-Class Standards?, Educational Leadership, 52, 6: 6-10.

Tharp, R.G., Estrada, P., Dalton, S.S., dan Yamauchi, L.A. (2000). Teaching Transformed: Achieving Ecellence, Fairness, Inclusion, and Harmony. Boulder, Colorado: Westview Press

Tucker, M.S. dan J.B. Codding (1998). Standards for Our Schools: How to Set Them, Measure Them, and Reach Them. San Francisco: Jossey-Bass Publishers.

Umass. (2001). Competency-based Education. Available at http://www. umb.edu, tanggal 24 Januari 2002. 
University of Pennsylvania School of Dental Medicine (1999). Accreditation Update. Vol.I no.3.

Weiss,C.H. (1972). Evaluation Research: Methods of Assessing Program Effectiveness. Englewood Cliffs,N.J.: Prentice-Hall

Wineburg, S. (2001). Historical Thinking and Other Unnatural Acts: Charting the Future of Teaching the Past. Philadelphia: Temple University Press

\section{DOCUMENTS}

Peraturan Menteri Pendidikan dan Kebudayaan Nomor 67 Tahun 2013 tentang Kerangka Dasar dan Struktur Kurikulum Sekolah Dasar/Madrasah Ibtidaiyah
Peraturan Menteri Pendidikan dan Kebudayaan Nomor 68 Tahun 2013 tentang Kerangka Dasar dan Struktur Kurikulum Sekolah Menengah Pertama/Madrasah Tsanawiyah

Peraturan Menteri Pendidikan dan Kebudayaan Nomor 69 Tahun 2013 tentang Kerangka Dasar dan Struktur Kurikulum Sekolah Menengah Atas/ Madrasah Aliyah

Peraturan Menteri Pendidikan dan Kebudayaan Nomor 67 Tahun 2013 tentang Kerangka Dasar dan Struktur Kurikulum Sekolah Menengah Kejuruan

Peraturan Menteri Pendidikan dan Kebudayaan Nomor 81A Tahun 2013 tentang Implementasi Kurikulum 2013 